\title{
Business coaching: Implementation of promotion mix and establishment of loyalty programs for MSMEs in Indonesia during the COVID-19 pandemic
}

\author{
S. Fiddiny \& H. Suhaimi \\ Faculty of Economics and Business, University of Indonesia, Central Jakarta, Indonesia
}

\begin{abstract}
A number of MSMEs in Indonesia have experienced a decline in income due to the COVID-19 pandemic, forcing MSMEs to work harder to survive the pandemic. This study aims to help MSMEs in the culinary industry by conducting the business coaching method through qualitative research, in which the data were obtained from observations, surveys, and in-depth interviews. The solution taken for this problem was done by designing a promotion mix and establishing loyalty programs. The implemented promotion mix elements were sales promotion and digital/internet marketing designed in the form of discounted offline promotions and online through the MSME Instagram platform. In addition, the establishment of the loyalty program was done by collecting a customer database. The implementation results showed an increase in MSME sales during the COVID-19 pandemic.
\end{abstract}

\section{INTRODUCTION}

According to data from the Indonesian Young Entrepreneurs Association, the pandemic has decreased the culinary industry's turnover by up to 30\% (Kompas.com, 2020). Warung Sop Ayam Mbah Min is one of the MSMEs in the culinary industry offering a product named Klaten chicken soup, which uses a family recipe passed down from generation to generation to maintain its quality. The COVID-19 pandemic also had a negative impact on this business, as reflected in the significant difference in the sales before the COVID-19 pandemic occurred and during the pandemic. In addition, government regulation had implemented Large-Scale Social Restrictions (PSBB, Pembatasan Sosial Berskala Besar), where all businesses and offices were not allowed to operate. Due to this, Warung Sop Ayam Mbah Min had to close its shop for approximately three months.

The following characteristics were obtained based on the results of the questionnaire distributed to 103 respondents:

Table 1. Profile respondents.

\begin{tabular}{lr}
\hline Gender & \\
\hline Men & $52 \%$ \\
Woman & $48 \%$ \\
Age & \\
$17-25$ year & $39 \%$ \\
$26-35$ year & $30 \%$ \\
$36-45$ year & $27 \%$ \\
$46-55$ year & $3 \%$ \\
$>55$ year & $1 \%$ \\
\hline
\end{tabular}

(continued) 
Table 1. Continued.

\begin{tabular}{lr}
\hline Gender & \\
\hline Occupation & \\
College Students & $25 \%$ \\
BUMN Employees & $22 \%$ \\
Private Employees & $35 \%$ \\
Civil Servants & $8 \%$ \\
Others & $10 \%$ \\
Monthly Expenses & \\
$>$ Rp700,000 & $9 \%$ \\
Rp700,000-Rp1,000,000 & $8 \%$ \\
Rp1,000,001-Rp2,000,000 & $28 \%$ \\
Rp2,000,001-Rp3,000,000 & $22 \%$ \\
$>$ Rp3,000,000 & $33 \%$ \\
\hline
\end{tabular}

The survey aims to determine the respondents' brand awareness, purchase intention, and customer loyalty toward Warung Sop Ayam Mbah Min. The survey results were gathered using an online survey method. From the results of this study, it was known that the brand awareness of Warung Sop Ayam Mbah Min was relatively high: there were $60.3 \%$ of respondents who knew the MSME, but only $50.8 \%$ of the respondents had made purchases, and $49.2 \%$ had never made purchases. The questionnaire results also demonstrated the respondents' intention to make purchases at Warung Sop Ayam Mbah Min. It is known that the average value of purchase intention was only 3.07 on a scale of 5 . This value is small, considering the average capability of the respondents to make purchases. Thus, Warung Sop Ayam Mbah Min needs to make innovations to be able to attract potential customers to want to make purchases.

On the other hand, the loyalty possessed by customers of Warung Sop Ayam Mbah Min has the value of 3.25. According to Evanschitzky and Wunderlich (2006), there are three phases of attitudinal loyalty, namely, cognitive loyalty, affective loyalty, and conative loyalty. Based on the value of the loyalty, customers of Warung Sop Ayam Mbah Min were still in the second phase, in which customers were satisfied with the services provided but have not entered into the third phase, where customers wanted to make repeated purchases of the products offered.

Based on the results of this survey, the MSME has not been implementing promotional activities to attract customers and establishing relationships with customers. With this background, this study aims to (1) implement the promotion mix for the MSME; and (2) create loyalty programs for the MSME.

\section{LITERATURE REVIEW}

According to Belch and Belch (2017), promotion is the coordination of the efforts made by sellers to prepare information channels and persuasion in the sales of goods and services or in promoting ideas. The basic tool that can be used to achieve organizational communication or promotion objectives is named a promotion mix. There are six elements of the promotion mix, which are advertising, direct marketing, digital/internet marketing, sales promotion, publicity/public relations, and personal selling.

According to Mullins and Walker (2013), maintaining customer loyalty is significant for business profits, especially in a mature market because loyal customers are more profitable. Companies can avoid spending high costs to get new customers and obtain loyal customers who tend to make continuous purchases and provide reviews or recommendations through positive word of mouth and are willing to pay high prices to get the desired product. Companies need to measure customer satisfaction regularly because a dissatisfied customer is unlikely to remain loyal over time. The 
main step in measuring customer satisfaction is examining customer behavior, such as frequency of purchases, the percentage of total customer purchases, and the company's ability to resolve complaints of any problems given by customers.

Loyalty programs are a powerful way for companies to increase customer retention and the volume or frequency of purchases (Bijmolt, Dorotic, \& Verhoef, 2011; Bolton, Kannan, \& Bramlett, 2000). The loyalty program is also a medium for service companies to start and maintain relationships with their customers so that they become long-term relationships (Bijmotl et al., 2011). An important element of a loyalty program is the reward structure and how it can change the purchasing and behavior of its members (Melancon, Noble, \& Noble, 2011; Zhang \& Breugelmans, 2012).

\section{RESEARCH METHODOLOGY}

This research is a qualitative study using a case study where the object of research is one of the MSMEs in Indonesia named Warung Sop Ayam Mbah Min, which was done by using primary data and secondary data.

Primary data were obtained by conducting the following: (1) in-depth interviews; (2) observations; and (3) surveys. In-depth interviews were conducted with the owners of Warung Sop Ayam Mbah Min to determine the business processes, including the internal and external problems that occurred. Observations were made during the operating hours of Warung Sop Ayam Mbah Min to determine the customers' behaviors. An online survey of 103 respondents was then conducted to determine customers' opinions regarding the strengths and weaknesses of Warung Sop Ayam Mbah Min. Secondary data used in this study were the related research journals discussing promotion and loyalty programs. In addition, the data obtained were analyzed to identify gap and Pareto analysis, which were then used to determine the alternative solutions and implement these solutions.

\section{RESULT AND DISCUSSION}

\subsection{Implementation of promotion activities}

Sales promotions were implemented to increase sales during the COVID-19 pandemic through online and offline activities. In online sales promotion, Warung Sop Ayam Mbah Min collaborated with an online food delivery application where customers were given free delivery fees and discounted prices on selected menus. The collaboration was carried out because the COVID-19 pandemic limits people's mobility; hence, many opted to purchase food through online food delivery. The implemented promotion was customer-oriented, where sales promotions targeted customers by giving discounts. Meanwhile, in offline sales promotion, Warung Sop Ayam Mbah Min applied four promotions as follows: (1) "MIN" Promo, where customers could eat for free if their name contains "min"; (2) Birthday Promo, where customers who were born in a certain month got 50\% discount; (3) Rp5,000 Discount Promo, where customers got Rp 5,000 discount in the fourth week of each month; and (4) Independence Day Promo, where customers got a 'buy one get one' for those who made purchase on August 17, 2020. These promos were printed on a tent card placed on each table at the shop so that interested customers could find out about ongoing promotions.

Digital/internet marketing was used to complement sales promotion by communicating ongoing promotions on social media. Offline promotions carried out by Warung Sop Ayam Mbah Min needed to be advertised, so that the target audience could find out information about the promo. The social media utilized for this was Instagram, using an account owned by Warung Sop Ayam Mbah Min.

\subsection{Loyalty program implementation}

The application of the loyalty program was proposed by the authors as a solution to the problems and desires of the owner, considering that Warung Sop Ayam Mbah Min MSME had difficulty in 
maintaining long-term relationships with customers and increasing sales. The loyalty program's implementation begins with collecting the customer database, which was then entered in the system owned by MSME. The customer database was gathered by filling in the criticism and suggestion forms and is carried out in conjunction with the ongoing promotions at Warung Sop Ayam Mbah Min. The criticism and suggestion form was the preferred by the owner to find out the strengths and weaknesses of the shop from the customers' point of view. Customers who filled out the form were given free drinks.

The customer database was entered into the cashier system owned by Warung Sop Ayam Mbah Min. Customers who had registered were be given points for each arrival to determine the frequency of visits. The collection of points was carried out by the customer, and it could be exchanged for vouchers or a discounted price.

\section{CONCLUSION}

The problems faced by MSMEs during the COVID-19 pandemic were due to not carrying out promotional activities and not establishing long-term relationships with their customers. Hence, the solutions to these problems are to carry out the promotion mix and establish loyalty programs. These solutions carried out by MSMEs during the COVID-19 pandemic resulted in an increase in income by $17 \%$ compared to the previous month. Thus, it can be concluded that the implementation of these solutions can help MSMEs in increasing sales during the COVID-19 pandemic.

The limitations of this research are that it covers only the marketing aspects and can still be developed into other managerial aspects, and it involved only Warung Sop Ayam Mbah Min, the MSME being researched.

\section{REFERENCES}

Belch, G. E., \& Belch, M. A. (2017). Advertising and Promotion: An Integrated Marketing Communications Perspective (11th Ed.). McGraw Hill Education.

Bijmolt, T. H. A., Dorotic, M., \& Verhoef, P. C. (2011). Loyalty programs: Generalizations on their adoption, effectiveness and design. Foundation and Trends in Marketing, 5(4), 197-258.

Bolton, R. N., Kannan, P. K., \& Bramlett, M. D. (2000). Implications of loyalty programs and service experiences for customer retention and value. Journal of the Academy of Marketing Science, 28(1), 95-108.

Dorotic, M., Verhoef, P. C., Fok, D., \& Bijmolt, T. H. A. (2014). Reward redemption effects in a loyalty program when customers choose how much and when to redeem. International Journal of Research in Marketing, 31, 339-355.

Melancon, J. P., Noble, S. M., \& Noble, C. H. (2011). Managing rewards to enhance relational worth. Journal of the Academy of Marketing Science, 39(3), 341-362.

Mullins, J. W. (John W., \& Walker, O. C. (2012). Marketing management: a strategic decisionmaking approach (8th Ed.). McGraw-Hill. 